DOI 10.15393/j9.art.2014.737

Наталья Петровна Видмарович

доктор филологических наук, ординарный профессор кафедры русского языка, Отделение восточнославянских языков и литератур, Загребский университет

(Загреб, Хорватия) natalija.vidmarovic@ffzg.hr

\title{
АПОСТАСИЙНОЕ НАЧАЯО В РАССКАЗЕ М. Н. ЗАГОСКИНА «КОНЦЕРТ БЕСОВ»
}

Аннотация. Тема искушения верой является одной из основных тем в цикле фантастических рассказов М.Н. Загоскина «Вечер на Хопре». В статье рассматривается механизм действия апостасийного начала на человеческую личность на примере рассказа из упомянутого цикла - «Концерт бесов». Главный персонаж рассказа оказывается перед выбором между «ветхостью», коснением во грехе или обновлением человеческого естества, между тлением и смертью или воскресением и бессмертием. Время действия - канун и первая неделя Великого Поста - позволяет проанализировать страстное состояние героя прежде всего в контексте великопостного покаянного канона Андрея Критского и ветхозаветных чтений об Адаме и Еве. Место действия - бал-маскарад - определяет способы действия апостасии: инфернальное маскируется под человеческое, пытаясь подменить лик - маской, личиной. Проявление апостасии дается с проекцией на современность, поскольку с секуляризацией общества возрастает агрессивность апостасии; несколько меняются внешние формы ее действия при сохранении сути.

Ключевые слова: апостасия, канон, Андрей Критский, Великий пост, маскарад

P ассказ М.Н. Загоскина «Концерт бесов» является частью цикла «Вечер на Хопре», состоящего из шести новелл и вступления, которое и по своему объему, и по тематике служит не только экспозицией к циклу, но содержит и отдельное повествование, тематически связанное с заключительной новеллой «Ночной поезд» ${ }^{1}$ Необходимо отметить, что вступление и последняя новелла при этом несут важную смысловую нагрузку: в них недвусмысленно подтверждается истинность того, о чем рассказывали участники «Вечера на Хопре» - гости помещика Асанова. Другими словами, ворос о противопоставлении двух мнений, высказанных гостями, - скептического и рассудочного, с одной стороны, и склонного вере в сверхъестественное, с другой - решается 
в пользу второго, причем когда наиболее убежденный сторонник разумного объяснения всех необычных происшествий - Заруцкий, сам убеждается в трагической истинности того, что казалось ему ранее невозможным. Не случайно, кстати, события повествований, служащих обрамлением цикла, происходят на Фомину неделю. Символической в этом смысле можно посчитать также связанность новелл местом действия: в трех новеллах — «Пан Твардовский», «Две невестки» и «Белое привидение» события развертываются в Польше и Италии; а в рассказах «Нежданные гости», «Концерт бесов», вступлении и заключительном «Ночном поезде» - в России; при этом, всем «заграничным» фантастическим происшествиям находится вполне рациональное объяснение, а вопрос о вымышленности историй, случившихся в России, все же остается открытым. Однако причину убежденности автора в достоверности услышанных им былей и преданий, по-видимому, следует прежде всего искать в том, что главным в «русских» новеллах оказываются размышления автора над вопросами искушения верой. Они и сообщают событиям подлинность, несмотря на нередко подчеркнуто фантастический сюжет, какой имеет место и в рассказе «Концерт бесов». Кстати, эта нарочитость, позволяющая заранее предвидеть ход событий и угадать возможный конец, как раз и указывает на глубинные смыслы повествований.

Рассказчик встречает в Москве на маскараде своего друга Зорина, недавно вернувшегося из Италии, любителя итальянской музыки и поклонника певицы Лауретты, с которой его связывают страстные чувства. Своему приятелю Зорин даже показывает издали Лауретту, которая появляется на маскараде ровно в полночь, когда на хорах трубы оркестра возвещают о начале Великого поста. Красное домино Зорина и черный венециан Лауретты усиливают впечатление таинственности - по сути бесовщины; эффект достигает высшей точки, когда Зорин снимает маску и рассказчик с ужасом констатирует, что его лицо похоже скорее на лицо мертвеца, нежели живого человека. В довершение всего рассказчик узнает, что Лауретта, собираясь оставить певческую карьеру, 
решает дать последний концерт, на который приглашен и ее возлюбленный. Причем время для репетиции концерта выбрано совершенно немыслимое - пятница первой недели Великого поста, когда любые увеселения исключены. Таким образом, день и час, поскольку концерт назначен еще и на полночь, подчеркивают его инфернальный характер. Когда Зорин появляется на концерте, вместо артистов и публики он видит сборище покойников, устраивающих в разгар игры оркестра бесовские выходки, жертвой которых становится он сам. Лауретта же, по окончании концерта снявшая маску, так же как и остальные, оказывается покойницей - и по сути посланницей ада. На следующее утро Зорина находят на площади без чувств. Повествование заканчивается скептическими репликами слушателей, особенно после сообщения рассказчика о том, что обо всем он узнал от самого Зорина, лишившегося после этого события рассудка.

И тем не менее эта довольно незатейливая «страшная» история, при всей своей простоте, скрывает в себе гораздо более глубокий смысл, чем может показаться на первый взгляд. Зорин с самого начала предстает человеком, страдающим тоской и унынием, для излечения которых доктор, поддавшись на уговоры друзей, предписывает Зорину в качестве лекарства посещения «балов, театров и маскарадов» $(334)^{2}$. Приняв это сомнительное предложение как возможный выход из мрачного состояния, Зорин немедленно наталкивается на лукавое предложение злого духа: в ответ на его ненасытную страсть итальянская певица Лауретта на вершине своей славы соглашается на неслыханную жертву - оставить сцену, навсегда покинуть Италию и переселиться в холодную Россию на постоянное жительство или, по романтическому определению Зорина, живой лечь в «обширную, холодную могилу» (335). Парадокс заключается в том, что Лауретта уже в могиле, а временно занявший ее место лукавый дух требует от него в обмен на вечную любовь всего лишь небольшую услугу - никуда не выходить из дома в последующие четыре дня и никого у себя не принимать. Правда, Зорин как будто уже пообещал отдать Лауретте свою душу - но сказанные в порыве страсти слова надо еще 
подкрепить и действиями - ведь не случайно Лауретта говорила о последнем и окончательном испытании любви к ней.

Поэтому внимание стоит обратить не столько на полночный час как начало поста и полночь пятницы как время концерта бесов в Ротонде, сколько на временной промежуток, отделяющий одну полночь от другой. Это первые четыре дня первой седмицы Великого поста, когда во всех храмах возносятся особенно усердные молитвы и совершается чтение Великого покаянного канона Андрея Критского. Канон - сочинение исключительное по силе своего покаянного чувства перед Богом и глубине осознания человеком своей греховности: не случайно оно открывается образами изгнанных из рая Адама и Евы.

Откуду начну плакати окаяннаго моего жития деяний? Кое ли положу начало, Христе, нынешнему рыданию? Но, яко благоутробен, даждь ми прегрешений оставление.

Гряди, окаянная душе, с плотию твоею, Зиждителю всех исповеждься и останися прочее преждняго безсловесия, и принеси Богу в покаянии слезы.

Первозданнаго Адама преступлению поревновав, познах себе обнажена от Бога и присносущнаго Царствия и сладости, грех ради моих.

Увы мне, окаянная душе, что уподобилася еси первей Еве? видела бо еси зле, и уязвилася еси горце, и коснулася еси древа, и вкусила еси дерзостно безсловесныя снеди.

Вместо Евы чувственныя мысленная ми бысть Ева, во плоти страстный помысл, показуяй сладкая и вкушаяй присно горькаго напоения.

Достойно из Едема изгнан бысть, яко не сохранив едину Твою, Спасе, заповедь Адам: аз же что постражду, отметая всегда животная Твоя словеса??

Тема изгнания не случайно затрагивается еще в сыропустную неделю перед Великим постом. Ведь Адаму и Еве предстоял труд по восстановлению в себе образа Божьего на пути возвращения утраченного рая. В этом и один из основных смыслов канона: обращаясь к лицам Ветхого Завета, он указывает на трагизм уже состоявшегося выбора между 
ветхостью и обновлением человеческого естества и возможность иного исхода в будущем. Раздавшийся на маскараде звук труб в знак начала поста также можно считать напоминанием - уже апокалиптическим - о том, что выбор, сделанный в этой временной жизни, предопределит вечную жизнь одним или вечные муки другим. Уход с маскарада Зорина и Лауретты - это почти символическая параллель к изгнанию первочеловеков из рая, почти, потому что здесь идет речь о добровольном уходе и сознательном избрании ветхости и богоотступничества, потрясающий образ которого изображен в арии, исполняемой Лауреттой на роковом концерте.

Первые четыре дня Великого поста, чтение покаянного канона Андрея Критского для верующих становятся одновременно и первой ступенью к восстановлению духовной и телесной чистоты. Это начало духовного поста, без которого пост телесный теряет свой смысл. Это время уединения, но молитвенного, это время воздыханий, сокрушения, очистительного плача. Для Зорина, грешника и богоотступника, это путь, противоположный пути покаяния, на котором вместо уединения и созерцательной молитвы его сотрясают лихорадка и страсти, вместо очистительных слез - струится холодный пот, а вместо воздержания от пищи герой соблюдает даже своеобразный телесный антипост:

Днем ходил я взад и вперед по моим комнатам, не мог ни за что приняться, горел как на огне, а ночью, - о мой друг! таких адских ночей не проводят и преступники накануне своей казни! <..> Не знаю, как дожил я до пятницы; помню только, что в последний день моего испытания мне не только не шла еда на ум, но я не мог даже выпить чашку чаю. Голова моя пылала, кровь не текла, а кипела в моих жилах. Помнится также, день был не праздничный, а мне казалось, что в Москве с утра до самой ночи не переставали звонить колокола. Передо мной лежали часы; когда стрелка стала подвигаться к полуночи, нетерпение мое превратилось в какое-то бешенство; я задыхался, меня била злая лихорадка, и холодный пот выступал на лице моем (340).

Примечательно, что окончание рассказа М. Н. Загоскин возвращает читателя к тому, что описывается вначале - 
к маскараду. И различие между двумя этими событиями состоит в том, что первый маскарад помимо всего прочего предстает профанацией Великого поста, поскольку комичностью масок сухоедения, гриба и капусты прикрывается снисходительное отношение к посту как времени вынужденного перерыва между периодами увеселений и светских развлечений. По сути это соотносится со скептической реакцией слушателей рассказа, сосредоточившихся прежде всего на фантастической стороне повествования. На втором же маскараде нечистые духи, прикидывающиеся людьми (причем умершими), пародируя человеческий род, пользуются в качестве масок человеческими лицами. Собственно, и маска Зорина на первом маскараде у Медокса скрывает то, что могло быть лицом на пути к лику, но находится в стадии превращения в личину.

- Ну, если ты меня не узнаешь, так смотри! - сказал человек в красном домино, приподымая свою маску.

Я невольно отскочил назад - сердце мое замерло от ужаса... Боже мой! так точно, это Зорин! это его черты!.. О, конечно!.. Это он, точно он!.. Когда будет лежать на столе, когда станут отпевать его... Но теперь... Нет, нет!.. Живой человек не может иметь такого лица! (335).

Сам Зорин объясняет эту перемену состоянием счастья и радости, совершенно, однако, не похожих на радость, которая светится в лице человека, отражающем свет Божий, поскольку любое лицо, скрывающееся под не пропускающей этот свет маской, мертвеет. По этой причине и четырехдневное душевное бешенство для Зорина увенчалось не просто концертом, но уродливым подобием пасхальной заутрени, на которой место воссиявшего света Воскресшего Христа занимают многочисленные погребальные огоньки, странным образом составляющие с тьмой единое целое: концерт, таким образом, предваряет погребение его собственной души. Маскарад в Ротонде, на котором духи тьмы властвуют над богоотступниками - и умершими телом, и живыми, но душевно мертвыми, для Зорина прозвучал ответом на его дерзкие слова об отречении от своей души, которую он дал Лауретте как самый драгоценный бессмертный дар взамен сердца: 
ведь по его словам оно всего лишь горсть пыли, его зароют в могиле, тогда как душа связана с бесконечной вечностью. То, что за этими словами читается нечто гораздо большее, чем просто влюбленность - подтверждает и неприятное чувство, которое испытал его собеседник. Слова Зорина стали вызовом Господу, тем более, что в своем сознании он провел четкую границу между тленным и нетленным, конечным и бесконечным, благословенным и греховным. Таким образом, грех плотской похоти был заслонен страшным грехом богоотступничества - апостасии, все глубины которой 3орин испытал уже на исходе четвертого дня по окончании чтения Канона Андрея Критского. Эти четыре дня в сжатом виде стали для него своеобразными мытарствами души, которые в запредельной реальности уже испытывала душа Лауретты во всей их - для нее ужасающей - справедливости.

После довольно усиленного аплодисмента вышла вперед Лауретта и, не снимая маски, запела совершенно незнакомую для меня арию. Слова были престранные: умирающая богоотступница прощалась с своим любовником; она пела, что в беспредельном пространстве и навсегда, с каждой протекшей минутою станет увеличиваться расстояние, их разделяющее; как вечность, будут бесконечны ее страдания, и их души, как свет и тьма, никогда не сольются друг с другом. Все это выражено было в превосходных стихах; а музыка!.. О, мой друг! где я найду слов, чтоб описать тебе ту неизъяснимую тоску, которая сжала мое бедное сердце, когда эти восхитительные и адские звуки заколебали воздух? В них не было ничего земного; но и небеса также не отражались в этом голосе, исполненном слез и рыданий. Я слышал и стоны осужденных на вечные мучения, и скрежет зубов, и вопли безнадежного отчаяния, и эти тяжкие вздохи, вырывающиеся из груди, истомленной страданиями. Когда посреди гремящего крещендо, составленного из самых диких и противуположных звуков, Лауретта вдруг остановилась, общее громогласное браво раздалось по зале... (343).

Момент концерта стал для Зорина откровением Страшного Суда, ибо подобно тому, как распятый Господь сходит во ад и освобождает души праведников, Зорин прикасается к аду получая о нем и зрительное, и слуховое и осязательное 
представление, буквально согрешая «зрением, слухом, обонянием, вкусом и осязанием», когда вся привычная система ценностей предстает для него в перевернутом виде. Невыносимые физические страдания (когда героя использовали в качестве музыкального инструмента и героиня фальшивила) соседствовали с неописумым наслаждением, когда Лауретта брала верный тон: а это означало, что реальная физическая боль при фальшивом тоне инфернального оркестра являлась отрезвляющим возвратом к жизни, в то время как восторг от гармоничных звуков гитары выступал восторженным самообольщением, выражавшимся в чувственных галлюцинациях.

Канон Андрея Критского в заключительных строках говорит о торжестве Евангелия, несущего Свет истины:

Новаго привожду ти Писания указания, вводящая тя, душе, ко умилению: праведным убо поревнуй, грешных же отвращайся и умилостиви Христа молитвами же, и пощеньми, и чистотою, и говением ${ }^{4}$.

Смысл совлечения ветхости и рождения в новом человечестве раскрывается в простых и величественных образах исцелившихся кровоточивой, расслабленного, блудницы и разбойника, в воскрешении умершего. Но ключ к душевному и телесному исцелению - в покаянии и смирении, которыми пронизано каждое слово канона:

Достойных покаяния плодов не истяжи от мене, ибо крепость моя во мне оскуде; сердце мне даруй присно сокрушенное, нищету же духовную: да сия Тебе принесу яко приятную жертву, Едине Спасе ${ }^{5}$.

В тяжкое искушение Зорин впадает по собственной воле, хотя до по-настоящему до конца не осознает всех его последствий. Возможно, именно по этой причине оно не приводит его к гибели, а становится «горьким врачевством», о котором говорят Отцы Церкви. Его «неизъяснимая тоска» во время исполнения арии подтвержает не вполне утраченную им способность различать, что не все «неземное» - есть небесное. Осознание приходит через физическую боль, а безумие неверия ограничивается сумасшествием, в чем проявляется 
поистине бесконечная милость Божья, поскольку оставшийся в живых Зорин понимает, что пережитое есть «нереальная» реальность - искушения, описываемые в Каноне Андрея Критского.

По окончании первой седмицы поста верующие нередко причащались в субботу, в день совершения церковью празднования памяти великомученика Феодора Тирона. И Феодор Тирон, и Андрей Критский жили во времена гонений на исповедников христианской веры. Андрей Критский в царствование Юлиана Отступника ${ }^{6}$, известного своими изощренными методами искоренения веры, когда под маской внешнего беспристрастия шло натравливание языческой толпы для жестокой расправы с христианами (нечто подобное пережил и Зорин на концерте: по указанию Лауретты музыканты бросаются на него, чтобы, искалечив, «приспособить» под музыкальный инструмент). Подвиги Феодора Тирона совершались в правление Константина Копронима - иконоборца. Восстановление в человеке Первообраза, опрометчиво отвергнутое Зориным и заявившее о себе на роковом концерте, - было смыслом жизни Феодора Тирона как истинного христианина, открыто посрамившего языческих богов. Свидетелем такого же посрамления стал и Зорин, на своем собственном примере. Как единственный живой человек на бесовском концерте, несмотря на все обольщения, он отчетливо видел, что свет Ротонды - ночной, жуткий, что мертвое - безобразно, а не прекрасно, что его любовь без Бога не имеет не только будущего, но причиняет ему невыносимые страдания, которые не очищают, но делают увечным - и физически (когда его ногу обгладывают ${ }^{7}$ ) и духовно (когда он становится душевнобольным).

Мотив маскарада, связанный с понятием апостасии, в целом нередко присутствует в литературе первой половины XIX века. Почти такое же описание бала под масками мы встречаем в рассказе В.Н. Олина «Странный бал», когда отставного генерала зазывает на бал, устроенный нечистой силой, случайно встретившийся ему на прогулке знакомый Вельский. Интересно отметить, что вначале генерал колеблется в выборе между намерением прочитать дома один- 
надцатую главу из Книги Бытия, в которой, между прочим, говорится о возведении Вавилонской башни, и предложением развлечься. На балу он переживает действительно вавилонское скопление злых духов по числу и разнообразию, которые по мере «вписывания» генерала в общую картину веселья, постепенно разоблачаются, освобождаясь от человеческих масок.

...я не буду описывать вам костюмов, кадрилей и масок; это бы значило употреблять во зло ваше терпение; скажу одним словом, что все они, более или менее, отличались вкусом и выбором; но были, однако ж, и маски странные, фантастические: например, тут ходила лошадиная нога, там ветряная мельница, размахивая своими крыльями; здесь летал безобразный нетопырь, там выступал скелет отвратительный: от всепожирающего разрушения уцелели одни только глаза, страшно вращавшиеся в их костяных орбитах; тут поражал зрение могильный вампир с окровавленною пастью, в истлевшем саване и с такими же волосами, готовыми разлететься пеплом при первом на них дуновении; там, вроде гнома, катилось что-то похожее на колесо без обода, и в ступицах коего, по обеим сторонам, пылали два страшные глаза, а вместо спиц торчали уродливые и тинистые руки; одним словом, противуположность была блистательная: жизнь, цветы и прелесть сливались с безобразием и гнусностию, и, обратно, безобразие и гнусность были смешаны с жизнию, цветами и очарованием. И в самом деле, то была прелестная маскерадная вечеринка! ${ }^{8}$

Маскирование инфернального под человеческое можно найти и в повести В. П. Титова «Уединенный домик на Васильевском», где бесовское скрывается уже не за откровенными масками и шумным весельем, но за некоторой необычностью костюмов, которую автор называет не стоящей внимания «мелочью»:

Дом ее стоял в не очень шумной улице и снаружи не представлял ничего отличного; но внутри - богатое убранство, освещение. Варфоломей уже заранее уведомил Павла, что на первый взгляд иное покажется ему странным; ибо графиня недавно приехала из чужих краев, живет на тамошний лад и принимает к себе общество небольшое, но зато лучшее в городе. Они застали нескольких пожилых людей, которые отличались высокими парика- 
ми, шароварами огромной ширины, и не скидали перчаток во весь вечер. Это не совсем согласовалось с тогдашними модами среднего петербургского общества, которые одни были известны Павлу, но Павел уже положил себе за правило не удивляться ничему, да и когда ему было заметить сии мелочи?'

Еще одна мимикрия апостасии присутствует и в драме М.Ю. Лермонтова «Маскарад», персонажи которой обращены в карточную колоду, а игра становится средством манипуляций невидимого главного персонажа драмы, так что маскарад и маски играют роль всего лишь вспомогательной бутафории для разыгрывания спектакля со спланированным ходом действия и известным концом.

Объединяющим началом для всех описанных случаев является и ощущение их "нормальности» и «привычности» для новых участников. Оно длится, правда, лишь определенный промежуток времени, сколько длится само одурманивание, однако можно заметить, что эти промежутки становятся длиннее. Это важно отметить, поскольку все та же личина апостасии со всеми прежними атрибутами и символикой присутствовала и в кощунственном «молебне» в Храме Христа Спасителя. Время действия - 21 февраля, на масленичной неделе накануне Великого поста. Скрывающие лица маски, похожие на тыквы хэллоуина, служили не только поруганию веры: суть хэллоуина как дня, посвященного нечистым духам, несмотря на все попытки придать ему добродушный характер веселых «колядок» под масками, состоит в утверждении языческих начал в противоположность христианским $^{10}$.

...нужно было сесть в тюрьму аккурат перед Великим постом.

И так сесть, чтобы оставаться в тюрьме и на Пасху. <...> Они замахнулись выше, на Иисуса Христа. И своим заточением хотели не то чтоб сорвать праздник Пасхи, но спародировать его, высмеять. Тюремная пайка профанировала Великий пост. Тюремные страдания имитировали Страстную неделю. <..> Адописные иконы Pussy Riot появились сразу после их задержания. На Пасху появились крашеные яйца и куличи с ликами кощунниц ${ }^{11}$.

Неправославная, инородная неоязыческая суть группы явно себя обнаруживает даже через свое название Pussy Riot; 
а скрывание под масками подчеркивает не только «инаковость» по отношению к окружению, но «избранность» по отношению к церкви: пение и прыжки на солее спиной к алтарю - выглядят как антипроповедничество и «радение», соблазняющие окружение на согрешение «всеми чувствы», и многих действительно соблазнившие. Лауретте из «Концерта бесов» М.Н. Загоскина после исполнения песни, пришлось снять маску, но увиденное произвело на присутствующих совершенно различное впечатление:

...несколько голосов закричали: «Синьора Бальдуси, синьора Бальдуси! Покажитесь нам! Снимите вашу маску!» Лауретта повиновалась; маска упала к ее ногам... и что ж я увидел?.. Милосердый Боже!.. Вместо юного, цветущего лица моей Лауретты - иссохшую мертвую голову!!! Я онемел от удивления и ужаса, но зато остальные зрители заговорили все разом и подняли страшный шум. «Ах, какие прелести! - кричали они с восторгом, - посмотрите, какой череп, - точно из слоновой кости!.. А ротик, ротик! чудо! до самых ушей!.. Какое совершенство!.. Ах, как мило она оскалила на нас свои зубы!.. Какие кругленькие ямочки вместо глаз!.. Ну, красавица!» (343-344)

Привычность таких зрелищ для современной публики что во времена Загоскина было попросту немыслимым объясняет и равнодушную, и откровенно одобрительную ее реакцию на выступление Pussy Riot, которая, кстати, вполне сопоставима и с реакцией антигероев Загоскина, увидевших за иссохшей мертвой головой премиленький «оскал зубов».

И пожалуй, единственное, хотя и существенное, различие заключается лишь в том, что если во времена М. Н. Загоскина, апостасия довольствовалась ночными ротондами и частными домами, то теперь она дерзнула войти в Храм и приблизиться ко входу в алтарь - без революций и насилия. И объяснение тому можно найти даже не в последствиях всеобщей секуляризации, карнавализации, демократизации... и т. д. общественной жизни, но все в том же рассказе Загоскина, в простых, но исключительно глубокомысленных словах, которыми писатель и завершает свой рассказ:

Уверяю вас, что приятель мой вовсе не думал лгать, рассказывая мне это странное приключение <...> Он благодаря Бога еще 
не умер и живет по-прежнему в Петербурге, подле Обухова моста...

- В желтом доме? - прервал исправник.

- Вот этого не могу вам сказать! - продолжал спокойно Черемухин. - Может быть, его давно уже и перекрасили (345).

И почти та же концовка рассказа «Странный бал» В. Н. Олина:

И эта гистория действительно достоверная? - спросил Савва Трофимович. - Не подверженная ни малейшему сомнению, - отвечал путешественник, - я слышал ее от самого генерала, который только что оправился от белой горячки ${ }^{12}$.

Таким образом, раньше те, кого подозревали в участии в апостасийных «мероприятиях», находились либо «в белой горячке», либо «в желтом доме», теперь же в резервации для мракобесов и фанатиков оказались все те, кто не поддался соблазну белой горячки в обширном (правда, уже перекрашенном) желтом доме, где пребывает атеистическая здравомыслящая паства.

Допустим, <...> они не ведали, что творили, - пишет автор цитировавшейся выше интернет-статьи «Видна рука опытного организатора». - Ну, значит, их втёмную использовал сатана, который не входит в юрисдикцию Таганского суда. А если эта акция была всё-таки спланирована и рассчитана именно на такой результат, то <...> видна рука человека изощрённого, к тому же искушенного в богословии

Но если даже допустить, что случившееся есть всего лишь форма самовыражения, отдающая нелепицей, то внутренняя разрушительная, апостасийная суть не исчезает: ибо предвидение Н.В. Гоголя о том, что «тайна беззакония уже в действии» (2 Фес. 2:7), достаточно ощутимо во всех сторонах жизни. О ней говорят и строки на первый взгляд незатейливых, с современной точки зрения попросту забавных, наивных фантастических рассказов, которые, однако же, при ближайшем рассмотрении оказываются наполненными глубокими православными смыслами. 


\section{Примечания}

1 Во вступлении рассказывается о помещике Глинском, имение которого после его смерти и трагической кончины его дочери Софьи Павловны, купил Асанов: у него и гостил рассказчик вместе с племянником Асанова Заруцким. В молодости же Асанов был безнадежно влюблен в Софью Павловну, но молодые получили от Глинского отказ и Софья Павловна зачахла, а Асанов, побывав на войне, разбогател и поселился в бывшем имении Глинских. В заключении цикла новелл говорится о далеком пращуре Глинского, судьба которого, равно как и судьба его дочери, оказались сходными с судьбой его потомков конца XVIII века.

2 Рассказ Концерт бесов цитируется по изданию: Загоскин М. Н. Сочинения: В 2 т. М.: Художественная литература, 1987. Т. 2. С. 333-347. Рядом с цитатой в скобках указывается страница.

3 Великий покаянный канон и его творец, Преподобный Андрей, Apхиепископ Критский [Электронный pecypc] http://www.xxc.ru/ orthodox/pastor/v_kanon/text1.htm // http://www.xxc.ru/orthodox/pastor/ v_kanon/index.htm

Там же.

5 Там же.

6 В качестве иллюстрации можно привести интересный пример обращения в язычество посредством обмана. «У римлян издавна существовал обычай, в силу которого в день рождения императора, равно как и в других случаях, последний раздавал подарки своим солдатам, особенно отличившимся своею храбростию и точным исполнением требований военной дисциплины. Юлиан не замедлил воспользоваться этим случаем для осуществления своих планов относительно восстановления многобожия. В день раздачи наград он всегда являлся к солдатам окруженный государственными регалиями, среди которых на первом плане были помещены изображения языческих богов и, по древнему обычаю, приказывал ставить пред собою жертвенник, наполненный угольями и фимиамом. Когда легионеры один за другим приближались к императору за получением из рук его почетной награды, чиновники, окружавшие трон, предварительно требовали от них, чтобы они бросили на уголья несколько зерен фимиама и отдали честь государственным регалиям. C первого взгляда можно думать, что указанным распоряжением Юлиан хотел только восстановить древний обычай, вышедший из употребления в правление первых христианских императоров. Но при более внимательном исследовании обстоятельств этого дела 
нельзя не прийти к справедливому заключению, что здесь скрывался чрезвычайно тонкий и злой умысел. «Целое воинство, - замечает по этому случаю св. Григорий Богослов, - продавалось одним злоухищрением. Покорители вселенной падали от малого огня, от куска золота, от небольшого курения, и большая часть не чувствовали своего поражения, что было всего горестнее» (Георгий Орлов. Церковь Христова. Рассказы из истории христианской Церкви. Юлиан Отступник [Электронный ресурc]. URL: http://www.librarium. orthodoxy.ru/orlov/o_cont.htm ; http://www.librarium.orthodoxy.ru/ orlov/o_julian.htm

7 Несмотря на то что это «обгладывание» чисто символическое, и нога у Зорина оказывается поутру на своем месте, он сохраняет стойкое воспоминание о совершившейся «операции» и своей физической неполноценности. То же самое происходит, к примеру, и с Жоржем Бенгальским из «Мастера и Маргариты» М. Булгакова, который временами не может отделаться от ощущения отсутствия собственной головы, оторванной и заново приставленной демонами.

8 Олин В.Н. Странный бал // Русская романтическая новелла. М.: Художественная литература, 1989. С. 306.

9 Титов В.П. Уединенный домик на Васильевском // Русская романтическая новелла. М.: Художественная литература, 1989. С. 31-53. С. 37.

10 Как известно, хэллоуин отмечают в ночь на 1 ноября - это для католической церкви День всех святых или так называемый «день усопших».

11 Видна рука опытного организатора [Электронный ресурс]. URL: http://www.politonline.ru/ventilyator/10964.html

12 См. сноску 8. С. 309.

\section{Список литературы}

1. Орлов Г. Церковь Христова. Рассказы из истории христианской Церкви. Юлиан Отступник [Электронный ресурc]. URL: http://www. librarium.orthodoxy.ru/orlov/o_julian.htm (дата обращения: 10.07.2013). 
Natalia Petrovna Vidmarovich

Doctor of Philology, Ordinary Professor of Zagreb State University

(Zagreb, Chorvatija)

natalija.vidmarovic@ffzg.hr

\section{THE THEME OF APOSTASIS IN ZAGOSKIN'S CONCERT OF THE DEMONS}

Abstract. The topic of trial by faith is one of the main ones in the cycle of stories by M.N. Zagoskin The Evening on Khoper. The Author analyses the mechanism of the influence of apostasy essence on human nature in Zagoskin's Concert of the demons. The main character faces a choice between "dilapidation", ossifying in sins and the renewal of human nature, between the decay and death, or resurrection and immortality. The setting is Great Lents Eve and its first week. It allows analyzing the passionate state of the character mainly in the context of the Great Canon of Repentance of St. Andrew of Crete and Old Testament readings on Adam and Eve during the first week of Great Lent. The setting at the masquerade ball defines the way apostasy manifests: the infernal disguised as the human trying to replace the image with a mask, guise. Apostasy in this novel is projected onto the modern age, as far as along with society secularization the aggression of apostasy grows, the outer forms of manifestation somehow change with its essence remaining the same.

Keywords: apostasies, canon, Andrew of Crete, Great Lent, masquerade

\section{References}

1. Orlov G. Tserkov' Khristova. Rasskazy iz istorii khristianskoy tserkvi. Yulian Otstupnik [The Church of Christ. Stories from the history of the Christian Church. Julian the Apostate]. Available at: http://www.librarium. orthodoxy.ru/orlov/o_julian.htm (accessed 20 March 2014). 